Article

\title{
Market-Based Instruments for Ecosystem Services between Discourse and Reality: An Economic and Narrative Analysis
}

\author{
Géraldine Froger ${ }^{1,2, *}$, Valérie Boisvert ${ }^{3}$, Philippe Méral ${ }^{4}$, Jean-François Le Coq ${ }^{5}$, \\ Armelle Caron ${ }^{6}$ and Olivier Aznar ${ }^{7}$
}

1 LEREPS (Laboratoire d'Etude et de Recherche sur l'Economie, les Politiques et les Systèmes Sociaux), Manufacture des Tabacs, 21 allée de Brienne, 31042 Toulouse Cedex, France

2 Département sciences économiques et gestion, Université de Toulouse-Jean Jaurès, 5 allée Antonio Machado, 31058 Toulouse Cedex 9, France

3 IGD (Institut de géographie et durabilité), Université de Lausanne, Bâtiment Géopolis, Bureau 3522, CH-1015 Lausanne, Switzerland; E-Mail: valerie.boisvert@unil.ch

4 Institut de Recherche pour le Développement, IRD, UMR GRED (IRD-Université Montpellier 3 Paul Valery), BP 64501, 34394 Montpellier Cedex 5, France; E-Mail: philippe.meral@ird.fr

5 ART-Dev, CIRAD, 73 rue Jean-François Breton, 34398 Montpellier Cedex 5, France;

E-Mail: jean-francois.le_coq@cirad.fr

6 AgroParisTech ENGREF, 19 Avenue du Maine Paris Cedex 15, 75732 Paris, France; E-Mail: Armelle.Caron@engref.agroparistech.fr

7 UMR Métafort, VetAgroSup, 89 Avenue de 1'Europe BP35, 63370 Lempdes, France; E-Mail: olivier.aznar@vetagro-sup.fr

* Author to whom correspondence should be addressed; E-Mail: gfroger2001@yahoo.fr; Tel.: +33-561-128-715.

Academic Editor: Marc A. Rosen

Received: 28 April 2015 / Accepted: 13 August 2015 / Published: 25 August 2015

\begin{abstract}
Since the mid-1990s, the concept of ecosystem services has become increasingly popular in academic circles and among decision-makers. Because of its inclusive character, this concept has given rise to different interpretations in economics. Since its inception, it has been associated with the development of market-based instruments (MBIs) in conservation policies. From this perspective, the sustainable provision of ecosystem services is hindered by market failures (e.g., public good attributes, externalities) and prices that do not capture the full value of the natural assets. MBIs are therefore recommended. According to their promoters, they provide powerful incentives to conserve the environment while at the same time offering new sources of income to support rural livelihoods. Our paper contends that
\end{abstract}


different economic narratives, and associated representations of the market failure at stake with the provision of ecosystem services, may support different policy instruments that are all coined as MBIs. As an illustration, we analyze the economic discourse underlying payments for ecosystem services and eco-labels, and we underline the variety of institutional forms to which they give rise in order to emphasize the differences between discourse and practice.

Keywords: market-based instruments; ecosystem services; externalities; joint products; narratives; payments for ecosystem services; environmental certification

\section{Introduction}

Since the mid-1990s, the concept of ecosystem services (ES) has become increasingly popular in academic circles as well as among decision-makers [1]. The number of articles on ES in the international databases Web of Science and Scopus has multiplied by seven in 10 years [2]. Beyond the academic literature, a range of books and reports arising from international initiatives have been distributed and disseminated, such as the United Nations' Millennium Ecosystem Assessment [1], The Economics of Ecosystems and Biodiversity, a report initiated by the G8 [3], and the State of Food and Agriculture 2007 [4]. Several networks have also been launched since 2000 to promote and mainstream this concept into conservation policies and agendas. Some focus on the economics-environment nexus (Ecosystem Valuation, Earth Economics, Earthtrends, etc.), others are devoted to awareness-raising (Guardian Environment Network, Business Green, Ecoworldly, etc.), and still others (Conservation Finance Alliance, Katoomba group, Ecosystem Marketplace, Avoided Deforestation Partners, BBOP Learning Network, Nature Valuation, and Financing Network, etc.) focus on conservation funding. ES are the benefits people obtain from ecosystems [1]. The services provided by ecosystems sustain or protect human production or consumption activities or affect welfare in general. They are classed into four categories: provisioning services, regulating services, supporting services, and cultural services. They include material and non-material benefits derived from ecosystems in their natural state or modified by human practices.

Economics has played a major role in the emergence of the ES concept as an explicitly anthropocentric concept and has contributed to its dissemination and politicization [5]. However, beyond conjuring up images of a nature bent toward human welfare, this concept is still open to multiple interpretations in ecology as well as in social sciences [6-8]. The risk of this cross-disciplinary notion being turned into a hackneyed phrase, supporting neoliberal discourse and the re-labeling of public policy provisions as market-based instruments (MBIs), is often highlighted [9]. Indeed, the concept of ecosystem services has gained momentum and has gradually replaced mentions of nature and biodiversity in the formulation of environmental policies at the very time when the latter were overtaken by a neoliberal discursive contagion epitomized in the widespread adoption of the term "MBIs".

The definition of MBIs is very broad and comprehensive and this notion has prompted criticism along the same lines as ES. While referring to the market, this notion is not clearly anchored in economic theory. Its definition and scope are still debated, and the term is very loosely used to refer to a wide range of policy tools such as taxes, cap-and-trade allowances, eco-labels, carbon or biodiversity offsets, or 
payments for ecosystem services [10-12]. There is no consensual list nor commonly accepted classification of MBIs. They are defined through their opposition to command-and-control instruments. The market mechanism is used to set incentives via prices or quantities (or contracts). MBIs can be classified into three different groups: price-based, quantity-based, and market friction mechanisms [13]. The context in which they might be effective has been discussed in the literature [14] and their social, political, and ideological underpinnings have given rise to criticism [15]. Our chief interest here does not lie so much in these issues raised by MBIs in general as in MBIs in relation to ES, since these notions have united and mingled in the recent policy discourses they have come to epitomize.

The purpose of this paper is to explore the major economic narratives that are relied upon to legitimize MBIs for ES and to compare the expected features and outcomes of these institutional arrangements to their existing forms. After an account of the emergence of the ES concept, we review different interpretations and meanings attached to this concept in economics (Section 2). We show that economists legitimize market-based policies to protect ES by conceptualizing ES either as positive externalities or as joint products or services, for instance, of agricultural commodities. Then, we focus on mechanisms that are the most obviously associated with given economic representations of ES: payments for ecosystem services (Section 3) and eco-certification schemes (Section 4). This is followed by a discussion of the innovative nature of payments for ecosystem services (PES) and eco-labels as instruments for the provision of ecosystem services. We show the gap between the legitimizing narratives supporting these policy instruments and the real-life institutional arrangements in which they are embodied.

\section{The Concept of Ecosystem Services: From Inception to Economic Reception}

The publication of the Millennium Ecosystem Assessment synthesis report in 2005 was a key stage in the career of the ES concept. Its exposure since the turn of the century can best be analyzed in light of the origin of the concept in ecology and economics.

It has long been acknowledged that ecosystems play a positive role in human well-being. Daily [16] notes, for instance, that Plato's Critias refers to the role of forests in erosion prevention and watershed development. However, the term "ecosystem services" itself did not appear before the beginning of the 1970s, in relation to the development of environmentalism in the United States $[8,17]$ and to the neo-Malthusian theses of Paul and Anne Ehrlich [18,19]. These authors tried to raise awareness about the alarming pace of resource exhaustion, species extinction, and ecosystem conversion. To that purpose, they emphasized human dependence on nature and developed global ecology and ecosystem approaches [20]. They strove to demonstrate the critical contribution of the various services provided by ecosystems to human welfare.

The limitations of standard environmental economics to account for this dependence on nature were stressed from the 1980s by a group of economists and ecologists and led to the creation of ecological economics. In a plea for this new approach, Costanza and Daly [21] stated as their proposed objective to "envelop economics in an overall ecological framework" (p. 7). This need for a theoretical and methodological renewal was felt by several authors who concentrated on the development of an adequate analytical framework during the 1990s (e.g., [22,23]). The concept of ES was instrumental in this regard. Picturing biodiversity erosion as a threat for the provision of critical services and as a net loss in terms of welfare made the issue more tangible. 
A further step toward the affirmation of the links between ecosystem conservation and economics was taken at the end of the 1990s with the publication of Daily's book [16] and of the article of Costanza et al. [24] in Nature. For allegedly pragmatic reasons, these authors defend the monetary valuation of ecosystem services, arguing that, to quote Myers and Reichert [25] (p. xix), "we don't protect what we don't value". Because monetary valuation is supposed to be particularly appealing for decision-makers, it has become a key element of the conservationist rhetoric and advocacy. Although it was a much-debated topic within ecological economics during the 1990s, economic valuation of the environment has now become commonplace. Economics has become the language for environmental policies precisely when ES became a hegemonic concept in the field of conservation policies. The ES concept has been both a driver and an outcome of this evolution. Biodiversity loss has been rephrased in terms of market failure, and market-based instruments for the provision of ES, coupled with the suppression of perverse subsidies, are presented as solutions to halt species loss and ecosystem degradation [26,27]. The former policies, being based on regulation and preservation models that limited or prohibited the exploitation of endangered species and their habitats, as well as participatory approaches, have been "marginalized".

The mainstreaming of the ES concept in policy-making at different scales (international, national, local) is a cornerstone of the "new economy of nature", to paraphrase Daily and Ellison [28]. This is the main objective of the approach followed by The Economics of Ecosystems and Biodiversity (TEEB) initiative (2007-2012), which "calls for a change to the current economic paradigm; at the same time (...) acknowledges the persuasive power of economic reasoning in contemporary societies" (Ring et al. [29] (p. 15)).

The economic characterization of ES used to justify conservation builds on two major representations: ES as positive externalities (hereafter the "externalities narrative") and ES as joint products (hereafter the "joint products narrative"). The former narrative has given rise to dedicated market-like arrangements as ES became a matter of political concern. The latter narrative has led to the reconsideration of some ES (such as most provisioning services) that were already, at least to some extent, commoditized or associated with existing markets. Both of these are discussed below.

At the core of the "externalities narrative" is the two-fold definition of externalities (Baumol and Oates [30] (p. 17)):

(1) “An externality is present whenever some individual's (say A's) utility or production relationships include real (non-monetary) variables, whose values are chosen by others (persons, corporations, governments) without particular attention to the effects on A's welfare. (...) It should be noted also that this definition excludes cases for which an individual deliberately acts to affect the welfare of A."

(2) "The decision-maker whose activity affects others' utility levels or enters in their production functions does not receive (pay) in compensation for this activity an amount equal in value to the resulting (marginal) benefits or costs to others."

Considering ES as positive externalities implies that the proposed policy program to ensure their socially optimal provision is to have them internalized. In line with economic theory, this can be achieved through a transaction between the beneficiaries and the providers of the services in question, which may take different forms and either be direct or imply third parties. Various options can be followed: taxes or subsidies, contractual public policies, or direct contracts between service providers 
and beneficiaries (actually the whole range of environmental policy tools, from Pigovian taxes to Coasian contracts, through quota markets). The "externalities narrative" thus legitimizes and gives rise to a range of various mechanisms that have been grouped under the common heading of market-based instruments since the end of the 1980s [31]. We will focus on one of the most common market-based instruments in the context of ES provision, namely "payments for ecosystem services" (PES) schemes, in the next section to emphasize the controversies and the differences between narrative and practice.

The "package economy" approach [32] is the basis for the "joint products narrative" regarding ES that leads to the selection of other market-based instruments, such as environmental certification, as possible tools for ecosystem management. In this perspective, ES are considered bundles of functions (or attributes) that might be included in or attached to physical goods, following Lancaster [33]. Contrary to externalities, these bundles of functions are produced purposely, they are part of a differentiation strategy and are expected to generate rents. Beyond their intrinsic material features, products such as agricultural commodities are considered as repositories of values. They can be analyzed as "packages". For instance, they might encompass special commitments relating to the organization of the supply chain (about animal welfare, the use of agrochemicals, ethics, etc.). These are not, strictly speaking, "joint products", as described in economic theory, but rather "joint services". Recent years have witnessed an increase in the informational or immaterial content of agricultural goods to address rising concerns about health or the environment. These goods are sometimes referred to as "agricultural solutions" to stress that this change is driven by consumer demand and implies immaterial dimensions. What is produced and sold is a package of complementary services and goods [32]. For instance, certified shade-grown or bird-friendly coffee is cultivated and purchased with a view to protect the environment and to provide ES. It commands a premium price because it includes "services". Certification by an independent third party guarantees respect for specifications relating to the provision of specified ES. The higher prices commended by certified products on the markets could be considered evidence of the consumer's consent to pay for ES. From this viewpoint, eco-certification schemes-insofar as they relate to identifiable ES - can be considered market-based instruments for the provision of ES. This line of justification for eco-certification schemes has, however, been limited thus far. As we will show, the link between eco-certification and ES provision is tenuous and more difficult to substantiate than in the case of PES mechanisms.

The controversies and theoretical debates raised by these narratives can best be illustrated by critically analyzing the institutional arrangements to which they give rise, PES that are associated with the "externality narrative" (Section 3), and eco-certification issuing from the "joint products narrative" (Section 4).

\section{Payments for Ecosystem Services: From Discourse to Political Realities}

The "externality narrative", which is conveniently familiar for standard environmental economics, has been favored so far in the justification of MBIs in relation to the provision of ecosystem services. In line with this narrative, ES are internalized through instruments that are given the generic name of payments for environmental services or payments for ecosystem services (PES). The implementation of these mechanisms is therefore often justified by the existence of positive externalities (to be encouraged) or negative externalities (to be cut) induced by production activities (agriculture or forestry). They can 
allegedly provide powerful incentives to conserve the environment, while at the same time offering new sources of income to support rural livelihoods [34]. In the following, we will first analyze argumentative patterns and blind spots in the economic PES discourse, and then confront the PES discourse with its political realities in developing and industrialized countries. Indeed, PES schemes can take different forms according to the context, they seldom are true markets in the real world, and the promotion of PES often reflects a requalification of pre-existing public intervention systems.

In PES schemes, the beneficiaries or buyers of environmental services compensate or remunerate those who provide (or rather contribute to the provision of) the service. According to the "canonical" definition proposed by Wunder, PES are voluntary transactions conditional upon clearly defined environmental services between a provider and a beneficiary [35]. They must be conditional (i.e., user payments are contingent upon the service being effectively provided) and additional (i.e., they generate a higher level of ecosystem services than in a baseline scenario, without payment). According to their promoters, they reconcile individual and/or collective land use decisions with social goals in terms of natural resources management and biodiversity conservation. Actually, most policy instruments that have at least some of the distinctive features of what is held to be the "archetypical" PES are re-labeled as such. Therefore, real-life PES seldom meet all of these requirements, as aptly noted by commentators [36-39]. PES have been described as Coasian-type contracts to ensure the provision of ES. However, unlike pure Coasian negotiations, the parties involved in the transaction are not free to determine who pays whom. The PES discourse is not neutral in this regard. Most of the time, it assumes a beneficiary-pays (rather than polluter-pays) principle and, therefore, an implicit distribution of rights and correlated duties over resources and ecosystem services [40]. Indeed, the rights of so-called "providers" of services, whose activities favor conservation or who refrain from destructive practices, are given precedence over those of the beneficiaries, who must pay to have their claims to ES acknowledged. The frequent references to the Coase theorem in relation to PES tend to obscure the issues raised by this allocation of rights. Indeed, according to the Coase theorem, the initial distribution of property rights is neutral in the final outcome of the negotiation only on the condition that rights can be reallocated at no cost. This is definitely not the case with PES because laws or regulations define the entitlements of the parties involved in these mechanisms.

PES schemes do not fit within the Coasian ideal, and their economic characterization is therefore trickier than what might appear at first glance. The problems of defining the exact nature of the transactions involved in these mechanisms are reflected in the words used to describe them. Indeed, there is no widely accepted designation, and at least four different terms (payments, markets, rewards, and compensation) are used in this context [41]. The most frequent and generic word used in relation to PES is "payment", which is more a layman's term than an economic concept that could be associated unambiguously with a theoretical model. It implies a monetary transaction but does not rely on specific assumptions about the liability and property of the parties involved, nor does it apply to externalities. Although the most neutral word to describe transactions in relation to ES, it can still create ideological conflicts and some obstacles to the implementation of well-intentioned PES schemes. For instance, the project of the Fundación Natura Bolivia financed by Forest Trends, which is referred to as a PES mechanism abroad [42], is defined as a "reciprocal watershed management" project in Bolivia to prevent the use of the term "payment" in a spirit of conciliation in line with the country's political position against the commodification of nature [43]. The term "market", which has recently emerged in 
connection to ES (Markets for Ecosystem Services/MES), is obviously used to suggest their efficiency in referring explicitly to economic theorizing. It falsely conveys the idea of competition among a multitude of buyers and sellers, whereas in reality there are often direct contractual relations among very few beneficiaries and providers, without centralized information. Moreover, it can prove a double-edged sword: in developing countries, the term "market" is often associated with a threat of privatization and commodification of services that were freely or cheaply available [41]. The other terms used to describe PES express a shift towards stakeholders and their practices as justification for the transaction. "Reward" is reminiscent of merit, justice, and fair remuneration. It implies that the recipients have taken positive actions to supply ES, which is at odds with the presentation of the latter as externalities, e.g., unintentional outcomes of economic activities. Moreover, because service providers are rewarded even if providing services does not cost them anything, it may lead to conflicts when the environmental outcomes of the PES do not live up to the expectations [40]. Finally, the term "compensation" is also used. In such a perspective, the direct and opportunity costs supported by the service providers to fulfill their commitments under the PES system, e.g., change in location or practice, substantiate their claims for compensation [40]. In that case, the rationale for the transaction is not ES as such but the costs induced by the environmental policy, which is therefore treated as an infringement of prior rights and could itself be considered an externality. These terminology issues demonstrate that the internalization process at stake in PES, if any, is complex and subtle.

Beyond semantics, real-life PES mechanisms take various forms depending on countries. First, there has been a multiplication of PES contracts since the turn of the millennium in developing countries [44]. These contracts cover a very broad spectrum, ranging from national programs managed by governments to local projects of more limited scope funded by the private sector, NGOs, or cooperation agencies. The different elements of Wunder's definition of PES apply more or less depending on the number and type of ecosystem services involved, the payment mechanisms used, and the number of buyers and providers involved in the transaction $[27,35,45]$. The Costa Rican Pago Por Servicios Ambientales, which was established in 1996, is showcased as a flagship PES-labeled scheme. It provides payments (more precisely "rewards") to landowners according to their land uses-forest conservation, reforestation, sustainable management, etc. - with the justification that these land uses generate ES either locally or globally [46]. This program does not meet Coasian criteria, and it reflects a requalification of pre-existing public intervention systems, particularly in forest policy. Indeed, it encompasses and redefines the former system of subsidies implemented by the Costa Rican government to fight deforestation. One explanation for this situation is the signing in July 1995 of an agreement between Costa Rica and the International Monetary Fund (IMF) banning the Costa Rican government from paying subsidies to productive sectors. In that context, a new type of justification had to be found for supporting the forestry sector, shifting from a government support rationale to market-based instrument rhetoric [47]. This agreement was part of the negotiations for Costa Rica's entry to the WTO and negotiations between Costa Rica and the World Bank for a structural adjustment plan [48].

In industrialized countries, the most advertised PES are those based on voluntary contracts, which arise from "self-organized" bilateral negotiations after the Coasian model. One of the most often-cited examples is the Vittel case in France: the company has signed contracts with surrounding farmers whereby they commit themselves to either change their practices or give up their production in exchange for payments in order to maintain the quality of mineral water [49]. Aside from this emblematic case, 
the promotion of PES is usually reflected in a requalification of pre-existing public intervention systems, particularly in agricultural policy. Their purposes are relabeled in terms of promoting ES in a market-based or market-compatible fashion. This is particularly the case with certain agri-environmental measures established in Europe and the United States [50,51]. References to the provision of ES tend to replace earlier justifications based on rural development and the multi-functionality of agriculture [52,53], which featured prominently in European debates on reforming the Common Agricultural Policy. ES are a new discursive resource used to legitimate agricultural subsidies and support measures for farmers that would be challenged otherwise because of the distortions they are likely to generate for competition. Re-qualifying them as PES makes it possible to present them expressly as market-based instruments and not as protectionist tools while at the same time tapping into an international discourse (ES) and hence avoiding the European Union language register (e.g., the term "multifunctionality" and its reminiscence of the Common Agricultural Policy). Nevertheless, this tentative ecologizing of agricultural subsidies is not completely successful; the ES/PES debate is still viewed with distrust by developing countries (agricultural exporters) that perceive it as just another attempt to defend protectionist interests. Worldwide, Coasian contracts seem to be an exception rather than the rule in the organization and functioning of PES. The description of ES as externalities is most likely, in some cases, a specious argument to reinforce policies that are considered irrelevant and inefficient according to neoliberal standards and that are threatened as such.

Finally, the relevance and the results of PES are also controversial. According to Wunder [35] and Laurans et al. [34], PES as MBIs have great potential for halting the degradation of natural resources, attenuating the imperfections and limited successes of integrated conservation and development projects (ICDPs) or sustainable resource management, and mobilizing additional financial resources. They would also create opportunities, especially in developing countries, including diversification of incomes and activities, job creation, and capacity-building [14,54-56]. These are the theoretical advantages attached to market-like solutions according to the externality narrative. However, the analysis of real-life PES mechanisms leaves some doubt about their effectiveness, i.e., their ability to meet contractual environmental objectives. Their efficiency, their fairness, their legitimacy, and their sustainability are also questionable, as illustrated by Muradian et al. [11,36] and Legrand et al. [57]. Indeed, the contexts in which PES are developed are often characterized by imperfect and asymmetric information (scientific uncertainty, inadequate ecological knowledge, inappropriate methodology for controlling the status of environmental services, etc.) and imbalance of power, allowing strategic behaviors such as hijacking and appropriation of the instrument by stakeholders who were not initially targeted and funding capture. According to Coase himself, these are the very features that should exclude the development of contractual agreements along Coasian lines as internalizing instruments. Not surprisingly, such contracts sometimes result in the weakening of public authorities and policies, a degradation of ecological systems, limited innovation in sustainable practices, the commodification of biodiversity, and a worsening of inequalities. There is definitely a gap between the legitimizing economic discourse supporting PES development and the political and environmental realities in which it is applied.

From their very inception, PES mechanisms have been meant to provide for the supply of ES. It is therefore quite normal that they should appear as the privileged type of MBI to account for ES. However, environmental certification is sometimes referred to as well in this context $[10-12,58,59]$. 
The economic discursive devices underlying the re-designation of eco-certification as MBIs and their factual accuracy both deserve investigation.

\section{Eco-Certification: Recognition of Ecosystem Services as Joint Products?}

Several types of environmental certifications are now re-labeled as MBIs for the provision of ES, although their initial purposes and justifications were different. New objectives and a new corpus of justification are now attached to these instruments that are thus redefined in the process. As already mentioned, the "joint products narrative" supports the presentation of eco-certifications as possible MBIs for the provision of ES. In the following, we will examine to what extent this narrative measures up when tested against real-life arrangements.

Certification is defined by Bass et al. [60] (p. 2) as "a procedure by which a third party provides written assurance that a product, process or service conforms to specified standards, on the basis of an audit conducted to agreed procedures". Certification is justified by the fact it provides consumers with information and guarantees the characteristics of products [61]. It is particularly relevant when these features can neither be observed nor verified, either during the transaction or afterwards. These characteristics are called credence attributes. They may relate to the product itself or to the production process and processing techniques (impacts on the environment, labor conditions along the supply chain, etc.).

Eco-labels can be considered market instruments on several accounts. The producers voluntarily engage in certification and commit themselves to respect the associated standards. Eco-certification explicitly refers to the compliance with environmental criteria and standards. Certified products command a premium price that could be interpreted as a payment for the maintenance or supply of ecosystem services.

However, certification has not always been so clearly considered a market instrument. There have been progressive changes in this regard, especially over the last two decades. The early experiences of organic agriculture, i.e., safer and more sustainable agrofood systems embedded in biological processes [62], relied upon public labels and took place in Europe and the United States. The creation of the International Federation of Organic Agriculture Movements (IFOAM) in 1972 has favored the mainstreaming of these experiences and the spread of organic farming to the south. The distinctive signs applied to organic products have also diversified. In most countries, organic farming is currently organized and governed through a combination of public regulation and private certification schemes [63]. Many trademarks and certification tools that specifically refer to what could be termed biodiversity or ecosystem services have developed from the end of the 1990s for various products. In the coffee sector, in addition to generic organic labels and eco-labels, there are a growing number of specific certification tools, e.g., Bird Friendly, created in 1998 by the Smithsonian Migratory Bird Centre; Utz Kapeh (changed to Utz Certified), created in 1999 by a group of European large retailers; Rainforest Alliance, created in 2003 by the Sustainable Agriculture Network (SAN); C.A.F.É. practices (Coffee and Farmer Equity practices), created in 2004 by Starbucks; the Common Code for Coffee Community-4C, created in 2005 by private companies and international organizations of the coffee sector and supported by German cooperations; and, more recently, Nespresso AAA certification, developed by Nestlé in 2006 [64-66]. 
The discourse legitimizing their use within the context of the ES policy mix has been built up as well during the last decade. The alleged advantage of eco-certifications as candidate incentives to support the provision of ES is that these tools already exist and are well known and recognized by consumers. They rely on existing markets, whereas the future potential of ad hoc exchange mechanisms specially created to account for newly identified and defined ES is mere conjecture. Moreover, environmental certifications have met with growing success, particularly over the last decade [67]. These characteristics are considered material advantages over other possible policy tools that could argue for their widespread adoption for pragmatic reasons. The joint products narrative presented above has therefore been developed as a justification for the integration of certifications in surveys of MBIs for ES. However, in contrast with PES, this inclusion has not been promoted by practitioners or specialists of global value chains, standards, or labels. It stemmed instead from scholarly endeavor and is associated with attempts to inventory, classify, or compare MBIs $[10,12,68]$. Ad hoc legitimizing narratives have been drawn up in retrospect. Not surprisingly, the interpretation of certifications as MBIs for ES provision can appear as contrived. The expectations attached to these instruments attest to a lack of awareness of their actual functions. The discrepancy between the narrative legitimizing such a categorization and existing institutional arrangements is much larger than in the case of PES, and while the influence of the former is undeniable, it is not readily acknowledged and voiced by stakeholders. There is no broad consensus on these new discursive registers and claims.

Real-life certification tools have some distinctive features that should lead to a reassessment of their representations as MBIs for ES [69]. It must first be stressed that it does not make much sense to speak about eco-certification in general. In some countries, standards are formulated and overseen by the government, while in others they depend on private sector actors, with each one developing its own set of criteria. The specifications, the environmental requirements they include, and their monitoring conditions may vary greatly from one certification body to the next and from one product to the next. Most of them do not imply major changes in the farming practices or the processing techniques. It is therefore unlikely that they should provide additional benefits for the environment if they were to become widespread. For instance, it is often noted that many agricultural systems in the developing world are de facto organic and that, in such cases, formal certification may bring limited technical changes.

Beyond the diversity of eco-certification schemes, they have some common features that make their presentation as market-based or market-like and their relation with ES debatable.

Notwithstanding the expectations associated with the "joint products narrative", it proves difficult to connect eco-certifications in an unambiguous way with specific ES. Eco-certifications are not defined in reference to the places in which the products originate. Most of the time, the specifications relate to a given product (e.g., coffee, cotton) and can apply anywhere, regardless of the local context and area of production, without adaptation of the standards. The certification criteria pertain to farming practices or processing techniques and not to their environmental impacts, which might, however, be place-specific and, in any case, are often poorly understood. While the link between land use and carbon storage is well established, the relations between land use and biodiversity conservation have not been fully investigated. Moreover, the link between land-use and water services is often difficult to demonstrate because of the complexity of the water systems [70,71]. Eco-certification is an instrument for differentiating the products on the market. The premium prices derived from certification depend on the consumers' willingness to pay, which depends in turn on their perception of the product attributes and 
specificities. Certification criteria must be transparent and easy to monitor, and they should appeal to laypersons (such as the bird-friendly certification) rather than be based on accurate but complex and subtle ecological knowledge that cannot be summed up in a few simple indicators. The premium prices paid in this context can be considered, at best, very rough proxies of the value attached to the protection of the environment.

Presenting the premium prices paid for certified products as the willingness to pay for ecosystem services is therefore questionable. The higher price the producers receive for their certified products is, foremost, a means for them to cover the costs induced by certification and the prior formalization and standardization of processes and operations that were informal before. Furthermore, in practice, the producers, producing countries, and various types of labels and certifications are competing with one another, which might induce a downward trend in the premiums in the long run [72].

Finally, the benefits of eco-certification for the farmers and, hence, the assumed compensation they would receive for the ecosystem services they provide and the incentive it would create, are debatable. The only producers who can benefit from a premium price are those who comply with the environmental specifications, but there is little evidence of the reverse. Despite a growing demand, the supply of most certified products is still greater than the market outlets [73]. Even if they comply with the specifications, the producers are not guaranteed to sell all of their products at higher prices in certified marketing chains. Due to low demand, they might be obliged to sell the bulk of their products on the conventional market - at a price that does not account for the specific conditions of production. The distribution of the premium associated with product differentiation might not benefit the farmers. Downstream actors of the value chain might capture the differentiation rent, as has been demonstrated for the coffee value chain, which is dominated by roasters and retailers [74]. The farmers who have changed or adapted their practices to supply environmental services are not fully compensated for their efforts, while other actors who did nothing can use their position of strength to capture premiums. The rent distribution along the value chain is governed by the balance of power.

The interpretation of certifications as MBIs for ES tends to obscure the real nature and complexity of value chains and to create the appearance of a direct contractual negotiation between ES providers and beneficiaries, whereas many actors with various statuses are involved.

\section{Conclusions}

As we have shown, since its inception, the notion of ES has been associated with the development of market instruments in conservation policies. From this perspective, the sustainable provision of ES is hindered by market failures (e.g., public good attributes, externalities) and prices that do not capture the full value of the natural assets. Depending on how these issues are defined and prioritized, different types of instruments, implemented through different types of institutional arrangements, are suggested as policy tools. The craze for market development has also led to rethinking and rewording existing policy instruments as MBIs. It has even encouraged a shift in these arrangements, instilling market attributes into them.

A wide range of policy instruments, such as PES and eco-certification, reflecting various purposes and involving different actors are therefore presented as MBIs. They are characterized as such not only because of their inherent properties but also for the promise they show. The economic narratives that 
justify their adoption and development build on alleged rather than actual characteristics, associated with theoretical archetypes rather than existing institutional arrangements. We have emphasized the differences between discourse and practice. Considering policy tools as market-like or market-based tends to obscure the power relations underlying them and the regulatory framework within which they often take place. The contracts are presented as voluntary and are supposedly defined through mutually agreed terms, but in practice the law may restrict them. Similarly, the part played especially by state actors in the enforcement of so-called MBIs is often overlooked; they are presented as third parties, intermediaries, or brokers to fit within the Coasian ideal of bilateral contracts, but their influence is crucial. Finally, relabeling policy instruments as MBIs for the provision of ES does not negate their earlier organization and goals, e.g., the support of rural income and of small-scale family farming in marginal areas. The latter may impede the use of these tools for the promotion of ES. Indeed, while not completely unconnected, the pursuit of redistributive justice and local development and concerns for local environment protection may require distinct approaches and priorities.

The economic discourse on MBIs for ES has performative aspects that should be considered as such when studying these instruments. A thorough analysis of these narratives is therefore particularly enlightening to understand and possibly overcome the problems encountered in ES governance.

\section{Acknowledgments}

This research has been carried out within the context of the SERENA project, funded by the French National Research Agency (Systerra Programme, ANR-08-STRA-13; http://www.serena-anr.org). This research is also part of the INVALUABLE project (Valuations, Markets and Policies for Biodiversity \& Ecosystem Services), funded by the ERA-Net BiodivERsA, with the French national funder Agence Nationale de la Recherche (Convention 2011- EBID-003-02; Convention 2011-EBID-003-03), part of the 2011 BiodivERsA call for research proposals.

\section{Author Contributions}

All authors contributed to the work presented in this paper. All authors read and approved the manuscript.

\section{Conflicts of Interest}

The authors declare no conflict of interest.

\section{References}

1. Millennium Ecosystem Assesment. Ecosystems and Human Well-Being: Synthesis; Island Press: Washington, DC, USA, 2005.

2. Jeanneaux, P.; Aznar, O. Une analyse bibliométrique pour éclairer la mise à l'agenda scientifique des services environnementaux. VertigO 2012, doi:10.4000/vertigo.12908.

3. TEEB. The Economics of Ecosystems and Biodiversity: Ecological and Economic Foundations; Earthscan: London, UK, 2010. 
4. FAO. The State of Food and Agriculture 2007: Paying Farmers for Environmental Services; Food Agriculture Organization of the United Nations: Rome, Italy, 2007.

5. Pesche, D.; Méral, P.; Hrabanski, M.; Bonnin, M. Ecosystem services and payments for environmental services: Two sides of the same coin? In Governing the Provision of Ecosystem Services; Muradian, R., Rival, L., Eds.; Springer: London, UK, 2013; pp. 67-86.

6. Norgaard, R.B. Ecosystem services: From eye-opening metaphor to complexity blinder. Ecol. Econ. 2010, 69, 1219-1227.

7. Farley, J. Ecosystem services: The economics debate. Ecosys. Serv. 2012, 1, 40-49.

8. Braat, L.C.; de Groot, R. The ecosystem services agenda: Bridging the worlds of natural science and economics, conservation and development, and public and private policy. Ecosys. Serv. 2012, $1,4-15$.

9. Sullivan, S. Green capitalism, and the cultural poverty of constructing nature as service-provider. Radic. Anthropol. 2009, 3, 18-27.

10. Pirard, R.; Lapeyre, R. Classyfying market-based instruments for ecosystem services: A guide to the literature jungle. Ecosys. Serv. 2014, 9, 106-114.

11. Muradian, R.; Arsel, M.; Pellegrini, L.; Adaman, F.; Aguilar, B.; Agarwal, B.; Corbera, E.; Ezzine de Blas, D.; Farley, J.; Froger, G.; et al. Payments for ecosystem services and the fatal attraction of win-win solutions. Conserv. Lett. 2013, 6, 274-279.

12. Muradian, R.; Gómez-Baggethun, E. The institutional dimension of "market-based instruments" for governing ecosystem services: Introduction to the special issue. Soc. Natl. Resour. 2013, 26, 1113-1121.

13. Whitten, S.; van Bueren, M.; Collins, D. An Overview of Market-Based Instruments and Environmental Policy in Australia. Available online: http://citeseerx.ist.psu.edu/viewdoc/download?doi= 10.1.1.130.4038\&rep=rep1\&type=pdf (accessed on 13 August 2015).

14. Lockie, S. Market instruments, ecosystem services, and property rights: Assumptions and conditions for sustained social and ecological benefits. Land Use Policy 2013, 31, 90-98.

15. McAfee, K. The contradictory logic of global ecosystem services markets. Dev. Chang. 2012, 43, $105-131$.

16. Daily, G.C. Nature's Services: Societal Dependence on Natural Ecosystems; Island Press: Washington, DC, USA, 1997.

17. Mooney, H.A.; Ehrlich, P.R. Ecosystem services: A fragmentary history. In Nature's Services: Societal Dependence on Natural Ecosystems; Daily, G., Ed.; Island Press: Washington, DC, USA, 1997; pp. 11-19.

18. Ehrlich, P.R.; Ehrlich, A.H. Population, Resources, Environment: Issues in Human Ecology; W.H. Freeman: San Francisco, CA, USA, 1970.

19. Ehrlich, P.R.; Ehrlich, A.H.; Holdren, J.P. Ecoscience: Population Resources Environment; W.H. Freeman: San Francisco, CA, USA, 1977.

20. Gómez-Baggethun, E.; de Groot, R.; Lomas, P.L.; Montes, C. The history of ecosystem services in economic theory and practice: From early notions to markets and payment schemes. Ecol. Econ. 2010, 69, 1209-1218.

21. Costanza, R.; Daly, H.E. Toward an ecological economics. Ecol. Model. 1987, 38, 1-7.

22. De Groot, R.S. Environmental functions as a unifying concept for ecology and economics. Environmentalist 1987, 7, 105-109. 
23. Perrings, C.; Maler, K.G.; Folke, C.; Holling, C.S.; Jansson, B.-O. Biodiversity Loss: Economic and Ecological Issues; Cambridge University Press: Cambridge, UK; New York, NY, USA, 1995.

24. Costanza, R.; d'Arge, R.; de Groot, R.; Farber, S.; Grasso, M.; Hannon, B.; Limburg, K.; Naeem, S.; O'neill, R.V.; Paruelo, J.; et al. The value of the world's ecosystem services and natural capital. Nature 1997, 387, 253-260.

25. Myers, J.P.; Reichert, J.S. Perspectives on nature's services. In Nature's Services: Societal Dependence on Natural Ecosystems; Daily, G., Ed.; Island Press: Washington, DC, USA, 1997; pp. xvii-xx.

26. Heal, G. Valuing ecosystem services. Ecosystems 2000, 3, 24-30.

27. Landell-Mills, N.; Porras, I.T. Silver Bullet or Fools' Gold: Developing Markets for Forest Environmental Services and the Poor; International Institute for Environment and Development: Stevenage, UK, 2002.

28. Daily, G.C.; Ellison, K. The New Economy of Nature: The Quest to Make Conservation Profitable; Shearwater Books; Island Press: Washington, DC, USA, 2002.

29. Ring, I.; Hansjürgens, B.; Elmqvist, T.; Wittmer, H.; Sukhdev, P. Challenges in framing the economics of ecosystems and biodiversity: The TEEB initiative. Curr. Opin. Environ. Sustain. 2010, 2, 15-26.

30. Baumol, W.J.; Oates, W.E. The Theory of Environmental Policy; Cambridge University Press: New York, NY, USA, 1988.

31. Stavins, R.N. Project 88: Harnessing Market Forces to Protect Our Environment; Environmental Policy Institute: Washington, DC, USA, 1988.

32. Moati, P. L'économie des Bouquets: Les Marchés de Solutions Dans le Nouveau Capitalism; Éd. de l'Aube: Paris, France, 2009.

33. Lancaster, K.J. A new approach to consumer theory. J. Polit. Econ. 1966, 74, 132-157.

34. Laurans, Y.; Leménager, T.; Aoubid, S. Payments for Ecosystem Services: From Theory to Practice, What Are the Prospects for Developing Countries? AFD, Agence française de développement: Paris, France, 2012.

35. Wunder, S. Payments for Environmental Services: Some Nuts and Bolts; CIFOR: Bogor, Indonesia, 2005.

36. Muradian, R.; Corbera, E.; Pascual, U.; Kosoy, N.; May, P.H. Reconciling theory and practice: An alternative conceptual framework for understanding payments for environmental services. Ecol. Econ. 2010, 69, 1202-1208.

37. Wunder, S. Payments for environmental services: Institutional preconditions in developing countries. In International Conference on Payments for Ecosystem Services and Their Institutional Dimensions; CIVILand: Berlin, Germany, 2011.

38. Muradian, R.; Rival, L. Governing the Provision of Ecosystem Services; Springer: London, UK, 2013.

39. Sattler, C.; Matzdorf, B. PES in a nutshell: From definitions and origins to PES in practice-Approaches, design process and innovative aspects. Ecosys. Serv. 2013, 6, 2-11.

40. Swallow, B.M.; Kallesoe, M.F.; Iftikhar, U.A.; van Noordwijk, M.; Bracer, C.; Scherr, S.J.; Raju, K.V.; Poats, S.V.; Kumar Duraiappah, A.; Ochieng, B.O.; et al. Compensation and rewards for environmental services in the developing world: Framing pan-tropical analysis and comparison. Ecol. Soc. 2009, 14, Article 26. 
41. Wunder, S.; Vargas, M.T. Beyond "Markets": Why Terminology Matters, 2005.Guest editorial, The Ecosystem marketplace, Katoomba Group. Available online: http://www.ecosystemmarketplace.com/ articles/beyond-034-markets-034/ (accessed on 14 August 2015).

42. Asquith, N.; Vargas, M.T.; Wunder, S. Selling two environmental services: In-kind payments for bird habitat and watershed protection on Los Negros, Bolivia. Ecol. Econ. 2008, 65, 675-684.

43. Bétrisey, F.; Mager, C. Les paiements pour services environnementaux de la Fondation Natura Bolivia entre logiques réciprocitaires, redistributives et marchandes. Revue Française de Socio-Économie 2015, 15, 39-58.

44. Schomers, S.; Matzdorf, B. Payments for ecosystem services: A review and comparison of developing and industrialized countries. Ecosys. Serv. 2013, 6, 16-30.

45. Engel, S.; Pagiola, S.; Wunder, S. Designing payments for environmental services in theory and practice: An overview of the issues. Ecol. Econ. 2008, 65, 663-674.

46. Daniels, A.E.; Bagstad, K.; Esposito, V.; Moulaert, A.; Rodriguez, C.M. Understanding the impacts of Costa Rica's PES: Are we asking the right questions? Ecol. Econ. 2010, 69, 2116-2126.

47. Hrabanski, M.; Bidaud, C.; Le Coq, J.-F.; Méral, P. Environmental NGOs, policy entrepreneurs of market-based instruments for ecosystem services? A comparison of Costa Rica, Madagascar and France. For. Policy Econ. 2013, 37, 124-132.

48. Le Coq, J.-F.; Pesche, D.; Legrand, T.; Froger, G.; Saenz-Segura, F. La mise en politique des services environnementaux: la genèse du Programme de paiements pour services environnementaux au Costa Rica. VertigO 2012, 12, doi: 10.4000/vertigo.12920.

49. Perrot-Maître, D. The Vittel Payments for Ecosystem Services: A "Perfect” PES Case? International Institute for Environment and Development: London, UK, 2006.

50. Baylis, K.; Peplow, S.; Rausser, G.; Simon, L. Agri-environmental policies in the EU and United States: A comparison. Ecol. Econ. 2008, 65, 753-764.

51. Laurans, Y.; Aoubid, S. L'économie au secours de la biodiversité? La légende des Catskills revisitée. In Iddri Working Papers; Iddri: Paris, France, 2012; p. 14.

52. OECD. The Contribution of Amenities to Rural Development; OECD: Paris, France, 1994.

53. OECD. Multifunctionality: Towards an Analytical Framework; OECD: Paris, France, 2001.

54. Froger, G.; Legrand, T.; Maizière, P. Les paiements pour services environnementaux permettent-ils de lutter contre la pauvreté et la vulnérabilité dans les pays du sud? Revue Développement Durable et Territoire 2015, in press.

55. Greiner, R.; Stanley, O. More than money for conservation: exploring social co-benefts from PES schemes. Land Use Policy 2013, 31, 4-10.

56. Zammit, C. Landowners and conservation markets: social benefits from two Australian government programs. Land Use Policy 2013, 31, 11-16.

57. Legrand, T.; Froger, G.; Le Coq, J.-F. Institutional performance of payments for environmental services: An analysis of the Costa Rican program. Forest Policy Econ. 2013, 37, 115-123.

58. TEEB. The Economics of Ecosystems and Biodiversity for National and International Policy Makers-Summary: Responding to the Value of Nature; TEEB: Geneva, Switzerland, 2009. 
59. WBCSD; IUCN. Markets for Ecosystem Service: New Challenges and Opportunities for Business and the Environment; WBCSD: Geneva, Switzerland; WBCSD North America: Washington, DC, USA; IUCN: Gland, Switzerland, 2007. Available online: http://www.wbcsd.org/Pages/EDocument/ EDocumentDetails.aspx?ID=27 (accessed on 14 August 2015).

60. Bass, S.; Grieg-Gran, M.; Markopoulos, M.; Roberts, S.; Thornber, K. Certification's Impact on Forests, Stakeholders and Supply Chains; International Institute for Environment and Development (IIED): London, UK, 2001.

61. Ponte, S. Standards and Sustainability in the Coffee Sector; International Institute for Sustainable Development (IISD): Winnipeg, MB, Canada, 2004. Available online: http://www.iisd.org/pdf/ 2004/sci_coffee_standards.pdf (accessed on 14 August 2015).

62. Raynolds, L.T. Re-embedding global agriculture: The international organic and fair trade movements. Agric. Hum. Values 2000, 17, 297-309.

63. Willer, H.; Kilcher, L. The world of organic agriculture: Statistics and emerging trends 2011. In International Federation of Organic Agriculture Movements (IFOAM): Bonn; Research Institute of Organic Agriculture (FiBL): Frick, Switzerland, 2011.

64. Raynolds, L.T.; Murray, D.; Heller, A. Regulating sustainability in the coffee sector: A comparative analysis of third-party environmental and social certification initiatives. Agric. Hum. Values 2007, 24, 147-163.

65. Muradian, R.; Pelupessy, W. Governing the coffee chain: The role of voluntary regulatory systems. World Dev. 2005, 33, 2029-2044.

66. Soto, G.; Le Coq, J.F. Certification process in the coffee value chain: Achievements and limits to foster provision of environmental services. In Ecosystem Services from Agriculture and Agroforestry: Measurement and Payment; Rapidel, B., DeClerck, F., Le Coq, J.F., Beer, J., Eds.; Earthscan: London, UK, 2011; pp. 319-346.

67. Daddi, T.; Iraldo, F.; Testa, F. Environmental Certification for Organisations and Products: Management Approaches and Operational Tools; Routledge: London, UK, 2015.

68. Le Coq, J.-F.; Soto, G.; González Hernández, C. PES and Eco-Label. A comparative analysis of their limits and opportunities to foster environmental services provision. In Ecosystem Services from Agriculture and Agroforestry: Measurement and Payment; Rapidel, B., DeClerck, F., Le Coq, J.F., Beer, J., Eds.; Earthscan: London, UK, 2011; pp. 237-264.

69. Henson, S.; Humphrey, J. Understanding the complexities of private standards in global agri-food chains as they impact developing countries. J. Dev. Stud. 2010, 46, 1628-1646.

70. Chomitz, K.M.; Kumari, K. The domestic benefits of tropical forests: A critical review. World Bank Res. Obs. 1998, 13, 13-35.

71. Bruijnzeel, L.A. Hydrological functions of tropical forests: Not seeing the soil for the trees? Agric. Ecosyst. Environ. 2004, 104, 185-228.

72. Kilian, B.; Jones, C.; Pratt, L.; Villalobos, A. Is sustainable agriculture a viable strategy to improve farm income in central america? A case study on coffee. J. Bus. Res. 2006, 59, 322-330.

73. Giovannucci, D. The State of Sustainable Coffee: A Study of Twelve Major Markets; World Bank: Washington, DC, USA, 2003. 
74. Daviron, B.; Ponte, S. The Coffee Paradox: Global Markets, Commodity Trade and the Elusive Promise of Development; Zed books: London, UK, 2005.

(C) 2015 by the authors; licensee MDPI, Basel, Switzerland. This article is an open access article distributed under the terms and conditions of the Creative Commons Attribution license (http://creativecommons.org/licenses/by/4.0/). 